\title{
In Her Footsteps: The Legacy of Professor Mizuta Noriko
}

Linda Flores

This special issue of the Review of Japanese Culture and Society is dedicated to the life and works of Mizuta Noriko, renowned professor, university chancellor, author, poet, essayist, activist, and mentor. "Mizuta-sensei," as she is affectionately known, has paved the way for generations of scholars in the fields of literature - especially women's writing - Gender and Women's Studies. In this issue we invite readers to journey through some of Mizuta's most influential works, navigating the steps of a woman who has inspired so many over the course of a truly pioneering career. The Japanese title of one of her articles translated here aptly illustrates our objective in presenting the pieces included herein. Characteristic of her scholarship on women's writing, it is titled "When Women Narrate the Self: Personal Narratives in Modern Women's Literature" (Josei ga jiko o kataru toki-kindai josei bungaku to "jiko gatari” no kiseki). The word “kiseki" (軌跡) can be defined as either the “path one has taken" or as "traces, footprints left behind.” The first character, “ki” (軌), can refer to a "model” or “way of doing something," while the second, “seki" (跡), connotes "footsteps" or "marks."

This issue, guest edited by myself and Julia Bullock and carefully and painstakingly shepherded from start to completion by Review of Japanese Culture and Society editor Miya Elise Desjardins, encompasses both meanings of kiseki. First, the works offer a detailed "model," following the trajectory of Mizuta's intellectual and professional path through Section Editor Alisa Freedman's essay, "Noriko Mizuta: Biocritical Essay of a Literary Feminist and Global Scholar." The essay provides rare insight into Mizuta's life and careerthe experiences, opportunities, and challenges that molded and shaped her both personally and professionally. Distinguished professor of English, Gender, and Cultural Studies E. Ann Kaplan offers her recollections of Mizuta and emphasizes the breadth and depth of her achievements in her introductory essay. Mizuta's influence is such that one wonders what the intellectual landscape of Women's Studies would look like without her, a question prominent sociologist and scholar of Women's Studies Ueno Chizuko poses in her essay on Mizuta.

Secondly, the special issue offers a glimpse into the "footprints," or intellectual traces, of Mizuta's impressive body of scholarship. This includes reprints of some of her best-known English-language scholarship on work by writers both east and west. She addresses the literary figure of the "madwoman in the attic" in her piece "Feminine Failure and the Modern Hero: Mad Women in Sylvia Plath's The Bell Jar and Joan Didion's Play It As It Lays." She has also written widely on important Japanese women writers, exemplified by two works in this issue, "Literature, Ideology, and Women's Happiness: The Autobiographical Novels of Miyamoto Yuriko" and "Women's Self-Representation and Transformation of the Body: Kōno Taeko and Ogawa Yōko." The section on Mizuta's English-language scholarship also covers her work on comparative literature, such as "Natsume Sōseki on Poe," as well as her English translations and literary analyses of the works of modern Japanese poets in "Beyond Home and City: Poems by Ishigaki Rin and Shiraishi Kazuko." Poetry constitutes an important element in Mizuta's career, both as an object of critical investigation and as a creative endeavor. Scholar and poet Jordan Smith served as Section Editor for Part IV of this special issue, and in his contribution on Mizuta's own poetic works, he describes how her influence on him, as for many others, has been transformational. 
Mizuta has also made her mark, so to speak, in the fields of gender theory and literary studies in both English and Japanese, and this special issue includes translations of some of her most noteworthy Japanese scholarly articles, available in the English language for the first time. The topics of female expression and representations of women constitute some of the most important themes in Mizuta's Japanese scholarship. She has explored the use of trauma fiction in literature about the atomic bombings of Hiroshima and Nagasaki in her article "The Literature of Memory: Ōba Minako's Urashimaso - Literature, Traumatic Memory and Restorative Memory" (translated by Hannah Osborne). Female-authored narratives are also at the very heart of the aforementioned article "Josei ga jiko o kataru toki: kindai josei bungaku to 'jiko gatari' no kiseki," translated by Nadeschda Bachem as "When Women Narrate the Self: Personal Narratives in Modern Women's Literature" as well as in "The Desolate Self and Its Circular Search for The Absolute Other: Transgression and Dream in the Work of Takahashi Takako" (translated by Alessandro Castellini). Mizuta's work explores representations of women across a broad spectrum of time periods and genres, including "The Girl Double: On the Shōjo as Archetype in Modern Women's Self-Expression" (translated by James Garza) and "The Dream of the Yamanba - An Overview" (translated by Luciana Sanga). Mizuta's scholarly interests extend beyond the realm of literature and Gender Studies to include contemporary culture, as is evident in the Art in Focus section of this issue, presented by Reiko Tomii as Section Editor.

On June 15, 2019, students and faculty from around the world gathered at Pembroke College, University of Oxford for the third Tanaka Symposium in Japanese Studies to celebrate the scholarship and writings of Professor Mizuta Noriko. The 2019 event in her honor consisted of a keynote lecture, discussions of her scholarly works, a poetry reading, talks on translation and minority voices, and a student workshop where Oxford students translated some of Mizuta's recent poetry from Japanese into English.

In the morning session, I (Linda Flores, University of Oxford) reflected on my experience of studying under the tutelage of Mizuta-sensei as a research student at Josai International University. Julia Bullock (Emory University) focused on the importance of translation in contemporary Japanese literary studies from the perspective of both theory and praxis, and of Mizuta's significant contributions in this area. Hannah Osborne (University of East Anglia) discussed how she approached the translation of one of Mizuta's academic articles on trauma fiction and the complexities involved.

The afternoon session highlighted themes that have long been at the forefront of Mizuta's scholarship, including the roles that poetry and translation play in safeguarding minority voices. Hosted by Laurence Mann (University of Oxford), the session featured a talk on translating songs in the Jeju language (Jieun Kiaer, University of Oxford) and a video art presentation inspired by Ainu ethnographies (Eiko Soga, Ruskin School of Art, Oxford). In the translation workshop, delegates and students alike delighted in Mizuta's poetry reading of her works, which was followed by a student-focused workshop on translation. The workshop offered a rare opportunity for student translators to receive feedback on their work from senior academics and translation professionals, as well as from Mizuta herself, who offered insight into the creation and meanings of her poetry. Alongside Mizuta, Professor Wachi Yasuko, formerly of Josai International University, engaged in a lively discussion on translation and the challenges it poses.

In her keynote speech, Mizuta focused on two main themes: the yamanba, or the "mountain witch" figure of Japanese legend and lore, and translation. It was in fact the English 
translation of Ōba Minako's "The Smile of the Mountain Witch" (Yamanba no bishō) in the 1970s that served as the genesis of Mizuta's critical analysis of the yamanba. Mizuta spoke of the difficulties faced with selecting an appropriate English term to represent yamanba, and the nuances associated with it. "The Smile of the Mountain Witch" was published in 1982 in the collection Mizuta translated and edited together with Kyoko Iriye Selden, Stories by Contemporary Japanese Women Writers (M.E, Sharpe, 1982). Notably, this was the first volume of fictional work by contemporary Japanese women writers available in the English language, and it remains a staple on reading lists at universities across the globe. The significance of this publication cannot be overstated; at the time, English translations of fiction by Japanese women writers were still very limited in number. Mizuta and Selden also published Japanese Women Writers: Twentieth Century Short Fiction (M.E. Sharpe, 1991), and More Stories by Japanese Women Writers: An Anthology (M.E. Sharpe, 2011). These publications of literary translations of stories opened the eyes of the western world to the wealth of literature by Japanese women writers, whose work then became a focal point of scholarly attention. Moreover, this inspired translators to turn their craft to Japanese women's literature, a legacy that remains evident in the present day. One figure from Japanese women's writing, the eponymous mountain witch from Ōba's aforementioned story, has garnered much critical attention in both Japan and the west and has become a focal point of Mizuta's research.

In Öba's story the yamanba possesses supernatural powers such as the ability to read minds, and this enables her to conform to the expectations of patriarchal society. Keenly aware that her abilities distinguish her unfavorably at times from others, the yamanba quickly learns to conceal her preternatural talents. It is only by doing so that she is able to live a life disguised as an ordinary woman of the village. She marries and raises two children, but harbors within herself the desire to live a life free from the strictures of the "good wife, wise mother" model of femininity and the patriarchal family. At the end of the story, we witness the yamanba lying on her deathbed surrounded by her family, who she intuits wishes to be released from the burden of caring for her. She fantasizes about living a life wandering the mountains, like a true yamanba. When she sees her reflection in a pool of water, she observes a duality: half of her face is smiling, while the other bears a monstrous expression.

Mizuta's scholarship on Ōba's story has shed new light on the marginalized and frequently elusive yamanba in Japanese literature and culture, drawing attention to the yamanba's multifaceted nature. Mizuta has edited books on the yamanba together with art and literary critics, including the influential Stories of the Yamanba (Yamanba-tachi no monogatari; Gakugei Shorin, 2002) and a volume of literary criticism of works by Japanese women writers that focus on the figure of the yamanba titled Reading Contemporary Women's Literature: Stories of the Yamanba - The Current State of Feminism and Gender Criticism, Arts and Crafts (Gendai josei bungaku o yomu: yamanba-tachi no monogatari - feminizumu/jendā hihyō no genzai, 2017). Together with Öba, author of "The Smile of the Mountain Witch," she also published The Landscape of the Yamanba (Yamanba no iru fükei; Tabata Shoten, 1994).

The yamanba is a central character in many of Ōba's works, but influence of this figure extends well beyond Ōba's oeuvre. Indeed, Mizuta has written of the yamanba as an important metaphor for women who rebel against the repressive norms of patriarchal society or women who dare to dream of lives free from social expectations. These modern-day yamanba appear as characters in women's literature in various guises, including mothers, single women, wives, daughters, and mothers-in-law. Mizuta identifies them in the fiction of 
Japanese women writers in decades past, including Enchi Fumiko, Takahashi Takako, Tomioka Taeko, Shiraishi Kazuko, Tsushima Yūko, and others. The legacy of the yamanba, she argues, lives on in contemporary literature as well in the hands of writers such as Tawada Yōko, Yū Miri, Kawakami Hiromi, and Kakuta Mitsuyo. Mizuta suggests that we can perhaps understand the yamanba not only as a female figure of resistance, but also as a philosophy, or a way of life.

Mizuta's scholarship has served to amplify the creative voices of women, voices that have throughout history either been silenced or relegated to the margins of discourse. In doing so, she has enabled, encouraged, and empowered generations of scholars, students, and especially women to forge their own paths, to lay down their own tracks, and to find their own intellectual, literary, and poetic voices. It is noteworthy that all of this Mizuta has accomplished while raising her own five successful children, embodying the multiplicity of the female experience in her personal life as well as in her scholarship.

Those who have been fortunate enough to study under the guidance of Mizuta-sensei will recall fondly their experiences. Mizuta's seminars were well attended and highly anticipated events. In her zemi we explored topics ranging from Freudian psychoanalytic theory, the works of scholars such as Judith Butler, Ueno Chizuko, and Julia Kristeva alongside literature by Tsushima Yūko, Ōba Minako, and others. We discussed and debated images of women in folklore and literature, including kitsune onna (fox women), oni (demons), and, of course, the yamanba. Our seminar discussions transgressed boundaries of genre and generation, and we were challenged and encouraged by Mizuta's leadership and her vision. We were all her deshi - her acolytes - and in many ways, all her children. It is no exaggeration to say that Mizuta has inspired and will continue to inspire generations of scholars in the fields of Japanese literature, Women's Studies and Gender Studies in the west, Japan, and beyond. It is our sincere hope that this special issue highlighting some of Mizuta's most influential scholarly and creative work will be a kiseki-both an inspirational "model" and a manifestation of "footsteps"-for new and returning readers, offering all an opportunity to learn from and engage with her work. 